\title{
PERAN PENYUNTING DALAM DUNIA PENERBITAN
}

Sebagai seorang pelajar atau penuntut ilmu tentunya tidak akan terpisahkan dari kegiatan belajar, salah satu media dan sumber belajar yang digunakan mahasiswa ialah buku. Buku adalah suatu media cetak yang berisi berbagai ilmu pengetahuan yang diungkapkan lewat tulisan penulis/penyusun. Kelebihan buku teks sebagai media pembelajaran, antara lain: dapat berdampingan dengan media lain, dapat digunakan oleh semua kalangan, tidak memerlukan peralatan khusus dalam menggunakannya dan cara penggunaan mudah dan praktis(Asyhari \& Silvia, 2017). Dengan alasan ini buku sangatlah penting dan mendapat tempat yang strategis bagi pelajar, sekaligus menjadi peluang bisnis yang sangat menguntukkan bagi perusahaan penerbitan.

Seorang pembaca yang baik bukan hanya seorang yang memiliki kegemaran membaca, akan tetapi pembaca yang baik juga mengenal sumber bacaan yang baik, biasanya hal yang sangat diperhatikan seorang pembaca yang baik adalah penerbit buku. Penerbit adalah seorang yang memiliki modal berupa tempat percetakan dan kemudaan menerbitkan buku untuk disebarluaskan pada pembaca. Bila penerbit menerbitkan buku yang kurang berkualitas dapat dipastikan pembaca/pembeli akan merasa dirugikan dan tidak akan mau membeli dari penerbit yang bersangkutan. Apabila demikian, lambat laun penerbit akan gulung tikar karena tidak lagi mendapat kepercayaan dan tempat pemasaran kepada pembaca.

Dalam dunia percetakan atau penerbitan ada tiga komponen yang harus kita tahu antara lain penerbit, penulis, dan pembaca. Penerbit berarti pihak yang memiliki modal berupa perusahaan percetakan. Penerbit yang baik senantiasa memiliki kepercayaan bahwa sebuah naskah yang akan diterbitkan harus melalui tahap-tahap sedemikian rupa sehingga pantas/ siap diterbitkan. Naskah diartikan sebagai karangan seseorang yang belum diterbitkan sehingga memerlukan pihak yang menyiapkan naskah agar siap diterbitkan (Laksono, K., \& Parmin, J, 2014). Hal ini sangat penting karena pembaca akan memperhitungkannya, manakala buku yang terbit dari suatu perusahaan penerbitan itu baik pembaca akan tertarik dan membeli buku dari penerbit yang bersangkutan secara berkelanjutan, begitu pula sebaliknya. Penulis adalah pengarang atau orang yang menuangkan pikiran orisinalnya ke dalam bentuk tulisan. Seorang menulis melalui lima tahap, yaitu prewriting (prapenulisan), drafting (penulisan), revising (revisi), editing (pengeditan), dan publishing atau sharing (publikasi) (Ariningsih, Sumarwati, \& Saddhono, 2012). Namun tidak semua penulis mampu melakukanya sendiri jadi diperlukan kerja sama dengan pihak lain. 
Pembaca adalah orang yang menjadi sasaran dalam penjualan buku yang diterbitkan oleh penerbit. Ketiga pihak tersebut saling berkaitan satu sama lain dalam dunia percetakan.

Mekanisme di dunia percetakan, meliputi penulis yang telah menyelesaikan tulisan yang kemudian di kirim ke penerbitan, penerbit yang baik seyogianya menyeleksi tulisan tersebut disesuaikan dengan gaya selingkung penulisan penerbit itu. Gaya selingkung merupakan gaya penulisan yang menjadi ciri khas bagi perusahaan percetakan tertentu (Laksono, K., \& Parmin, J, 2014). Apabila suatu tulisan dicetak tanpa memperhatikan kualitas baik itu isi, kebahasaan, dan pilihan diksi sudah bisa dipastikan akan mengurangi minat pembaca untuk membeli buku dari perusahaan yang bersangkutan. Oleh karena itu, harus ada pihak yang menjembatani antara penulis, penerbit dan pembaca. Orang yang menjembatani antara penerbit dan penulis adalah penyunting yakni orang yang bekerja menyunting naskah sehingga layak terbit.

Penyuntingan adalah bentuk kata berimbuhan yang berasal dari kata sunting hiasan yang berarti dicocokkan ke depan atau belakang telinga (Pusat Bahasa Kemdikbud, 2016). Kata dasar sunting melahirkan bentuk turunan menyunting (kata kerja/verba), penyunting (kata benda/nomina) dan penyuntingan (kata benda/nomina) (Alwi, dkk, 2001:1106). Penyuntingan berkaitan dengan kegiatan menyunting yakni menyiapkan naskah siap cetak atau siap terbit dengan memperhatikan segi sistematika penyajian, isi, dan bahasa (menyangkut ejaan, diksi, dan struktur kalimat); mengedit, yaitu pekerjaan menyunting naskah yang betul-betul menjadi naskah yang siap untuk dicetak memerlukan keterampilan khusus. Penyunting merupakan orang yang mengatur, memperbaiki, merevisi, mengubah isi, dan gaya naskah orang lain, serta menyesuaikannya dengan suatu pola yang dibakukan, kemudian membawanya ke depan umum dalam bentuk terbitan (Rifai, 2004:86). Kata penyuntingan berarti proses, cara, perbuatan menyunting atau sunting-menyunting.

Kerja sama antara penerbit, penulis, dan pembaca dapat dalam dunia percetakan dapat terjalin dengan baik apabila ada pihak yang menjembatani antara ketiganya. Pihak yang dimaksud adakah penyunting dan editor. Tugas seorang penyunting adalah menyiapkan naskah agar siap terbit dengan mengubah suatu naskah agar sesuai dengan aturan kebahasaan yang baik dan benar (ejaan, struktur kalimat, diksi). Berbeda halnya dengan editor yang bertugas mengatur naskah dari segi isi dan sekaligus menentukan, mencari naskah yang selanjutnya akan disunting oleh penyunting/kopi editor. Kegiatan menyunting dari segi kebahasaan disebut dengan istilah mechanical editing, sedangkan kegiatan menyunting naskah dari segi isi/materi disebut dengan istilah substantial editing (Eneste, P, 2009). 


\section{Daftar Referensi}

Asyhari, A., \& Silvia, H. (2017). Pengembangan Media Pembelajaran Berupa Buletin dalam Bentuk Buku Saku untuk Pembelajran IPA Terpadu. Jurnal Ilmiah Pendidikan Fisika AlBiruni. https://doi.org/10.24042/jpifalbiruni.v5i1.100.

Ariningsih, N. E., Sumarwati, \& Saddhono, K. (2012). Analisis Kesalahan Berbahasa Indonesia Siswa Sekolah Analisis Kesalahan Berbahasa Indonesia Dalam Karangan Eksposisi Siswa Sekolah Menengah Atas. BASASTRA Jurnal Penelitian Bahasa, Sastra Indonesia Dan Pengajarannya. 1(1), 40-53

Alwi, Hasan (Ed.). (2001). Kamus Besar Bahasa Indonesia. Jakarta: Balai Pustaka.

Eneste, P. (2009). Buku Pintar Penyuntingan Naskah Edisi Kedua.

Laksono, K., \& Parmin, J. (2014). Penyuntingan.

Rifai, Mien A. (2004). Pegangan Gaya Penulisan, Penyuntingan dan Penerbitan. Yogyakarta: Gajah Mada University Press. 